\title{
Species of Wadicosa (Araneae, Lycosidae): transfer of two species from Pardosa and description of three new species from Africa
}

\author{
Torbjörn KRONESTEDT \\ Department of Zoology, Swedish Museum of Natural History, \\ Box 50007, SE-104 05 Stockholm, Sweden. \\ E-mail: torbjorn.kronestedt@,nrm.se \\ urn:Isid:zoobank.org:author:5B8B8AF1-F0B0-4E45-82F0-8A3B23B1D6DD
}

\begin{abstract}
Pardosa benadira Caporiacco, 1940 is redescribed, including the hitherto unknown female. The species is here transferred to the genus Wadicosa Zyuzin, 1985. Previously known only from its type locality in Somalia, additional localities for P. benadira in Somalia and Kenya are given. Male and female W. cognata sp. nov. (Kenya: Lake Magadi), male and female W. jocquei sp. nov. (Comoro Islands, Aldabra, Madagascar and Mauritius) and female W. russellsmithi sp. nov. (Mauritius) are described. Pardosa oncka Lawrence, 1927, widely distributed in Africa and redescribed by Kronestedt in 1987, is formally transferred to the genus Wadicosa and new records given.
\end{abstract}

Keywords. Taxonomy, Pardosa, Afrotropical Region, Comoro Islands, Aldabra, Madagascar, Mauritius.

Kronestedt, T. 2015. Species of Wadicosa (Araneae, Lycosidae): transfer of two species from Pardosa and description of three new species from Africa. European Journal of Taxonomy 132: 1-19. http://dx.doi.org/10.5852/ ejt.2015.132

\section{Introduction}

The genus Wadicosa was established by Zyuzin (1985) for some lycosid species previously placed in Pardosa, with Lycosa venatrix Lucas, 1846 as the type species. It was later shown (Wunderlich 1987) that Lycosa venatrix Lucas is not conspecific with Lycosa (or Pardosa) venatrix sensu auctores, which was the species Zyuzin (op. cit.) referred to when establishing the genus. The latter was instead identified with Lycosa fidelis Pickard-Cambridge, 1872, which was consequently formalized as the type species of Wadicosa (Kronestedt \& Zyuzin 2009).

Seven species are currently placed in Wadicosa: W. commoventa Zyuzin, 1985, W. daliensis Yin, Peng \& Zhang, 1997, W. fidelis, W. okinawensis (Tanaka, 1985), W. prasantae Ahmed et al., 2014, W. quadrifera (Gravely, 1924) and $W$. sp. from Borneo (Zehethofer 1998). In addition to these, Kronestedt (1987) listed some Old World species sharing characters which suggest their placement in Wadicosa, i.e., (ठ) tegulum with anterior retrolateral process pointing ventrad and ( $(+)$ epigyne with two more or less separated foveolae (Kronestedt \& Zyuzin 2009; foveolae termed pockets in Kronestedt 1987, 1993) in anterior part. Of these, Pardosa benadira Caporiacco, 1940 is here redescribed and transferred to Wadicosa, and Pardosa oncka Lawrence, 1927, redescribed in Kronestedt (1987), is formally transferred to Wadicosa. 
The original description and illustration of Pardosa benadira, as well as the redescription and illustrations in Roewer (1959), are poor ( $c f$. Fig. 2A-B) and a new description is provided here in order to make the species identifiable. The female here assigned to this species has previously not been described. The matching of the sexes was due to the collecting of both in two widely separated localities.

Wadicosa cognata sp. nov. is described based on material received from Dr Scott Miller and collected by him and collaborators at Lake Magadi, Kenya. Years ago, the author came across material now described as $W$. jocquei sp. nov. from the Comoro Islands, collected by Dr R. Jocqué during visits to these islands in 1981, 1983 and 1993, and from Aldabra. Additional material of this species revealed its occurrence on Madagascar and Mauritius. No Lycosidae species have previously been reported from Aldabra or Mauritius.

The material from Mauritius, collected by Dr A. Russell-Smith, also included a single female of an unknown species here described as Wadicosa russellsmithi sp. nov.

\section{Material and methods}

The material studied is preserved in the following collections:

$\mathrm{BMNH}=$ Natural History Museum, London

BPBM = Bernice P. Bishop Museum, Honolulu

CARS $=$ Collection of A. Russell-Smith

CAS $=$ California Academy of Sciences, San Francisco

MZUF $=$ Museo Zoologico de 'La Specola', Firenze

MRAC $=$ Musée Royal de l'Afrique Centrale, Tervuren

NHRS $=$ Swedish Museum of Natural History, Stockholm

NMKE $=$ National Museums of Kenya, Zoology Department, Nairobi

USNM = Smithsonian Institution, National Museum of Natural History, Washington D.C.

Micrographs were made using a Hitachi S-4300 scanning electron microscope at the NHRS. Digital colour photographs (stacked) of specimens in ethanol were taken with a Canon EOS 5D camera with Zerene Stacker (Fig. 1), and by using an Olympus SZX12 stereo microscope with a DeltaPix Infinity X camera and DeltaPix Insight software (for stacking) (Fig. 7) at the same museum.

Measurements refer to specified individuals and are given in mm except for eyes. Eyepiece micrometer units (given for eyes) can be converted to mm by dividing by 80 .

Terminology of palpal structures follows Kronestedt \& Zyuzin (2009).

The following abbreviations are used in the descriptions of taxa:

\section{Eyes}

$\mathrm{ALE}=$ anterior lateral

$\mathrm{AME}=$ anterior median

PLE = posterior lateral

$\mathrm{PME}=$ posterior median

Legs and palp

$\mathrm{Fe}=$ femur

$\mathrm{Pt}=$ patella 


$$
\begin{aligned}
& \mathrm{Ti}=\text { tibia } \\
& \mathrm{Mt}=\text { metatarsus } \\
& \mathrm{Ta}=\text { tarsus } \\
& \mathrm{Cy}=\text { cymbium }
\end{aligned}
$$

\section{Results}

Class Arachnida Cuvier, 1812

Order Araneae Clerck, 1757

Family Lycosidae Sundevall, 1833

Genus Wadicosa Zyuzin, 1985

Wadicosa benadira (Caporiacco, 1940) comb. nov. Figs 1A-C, 2A-D, 3A, D, 4A, D, 5C, D, 7A, 8A, D, 9; Table 1

Pardosa benadira Caporiacco, 1940: 770, fig. 1 (ふ). — Roewer 1959: 60, fig. 18 (ふ).

\section{Diagnosis}

The male differs from other Wadicosa species by a short, characteristically shaped embolus with a proximal conical protrusion (Fig. 2C-D); the female differs by the shape of the epigyne, having a characteristically shaped median depression which is longer than wide and flanked by two narrow elongate furrows (Figs 3D, 7A).

\section{Material examined}

\section{Lectotype}

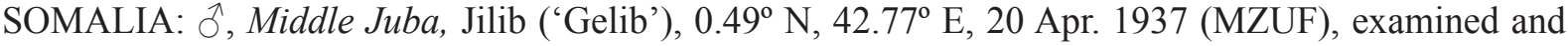
here designated.

\section{Other material}

KENYA: Isiolo, $5 \mathrm{~km}$ NNE of Isiolo, $0^{\circ} 24.3^{\prime} \mathrm{N}, 37^{\circ} 35.7^{\prime} \mathrm{E}, 19$ Jun. 1999, J.S. Schweikert \& W.J. Pulawski, 1 + (CAS-ENT 9046046). Laikipia, Mpala Ranch, $0^{\circ} 17^{`}$ N, 3752’ E, along edge of pond, 20 Apr. 2002, R. Jocqué \& C. Warui, 1 q (MRAC 212184). Marsabit, Marsabit National Reserve, Lake Paradise, $2^{\circ} 12^{\prime}$ N, $37^{\circ} 56^{\prime}$ E, bare soil on shore, 16 Jan. 1975, T. Kronestedt, $3{ }^{\circledR}{ }^{\AA}, 6$ 웅 (together with Wadicosa oncka) (NHRS). Kwale, $65 \mathrm{~km}$ WNW of Mombasa, at main road to Nairobi, $3^{\circ} 47^{\prime} \mathrm{S}$, $39^{\circ} 17^{\prime}$ E, open grassy vegetation at water hole, $3 \& 7$ Jan. 1972, T. Kronestedt, 1 đ , 5 + $q$ (together with W. oncka) (NHRS). Taita-Taveta, Tsavo East National Park, Mudanda Rock, $3^{\circ} 10^{\prime}$ S, $38^{\circ} 31^{\prime}$ E, dense grassy vegetation at small pool, 7 Jan. 1972, T. Kronestedt, 2 우 (together with $W$. oncka) (NHRS).

SOMALIA: same data as for lectotype, 1 đิ (single palp only). Middle Shabelle, Garsaale ('Gaersale'), $2.63^{\circ}$ N, $45.37^{\circ}$ E, 1 Aug. 1968, S.B.S. (Spedizione Biologica in Somalia del Centro di Studio per la Faunistica ed Ecologia Tropicali del Consiglio Nazionale delle Ricerche), 1 \& (MRAC 173158).

\section{Description}

Male (Kenya: WNW of Mombasa)

Total length $5.2 \mathrm{~mm}$; carapace $2.70 \mathrm{~mm}$ long, $2.10 \mathrm{~mm}$ wide.

Cephalothorax. Carapace brown to blackish brown with yellowish brown, wide, jagged-edged median field. No lateral bands. Sides of thoracic part with short dark recumbent hairs, median field in addition with dense pubescence of adpressed light hairs. Clypeus brown to blackish brown. Chelicerae brown to blackish brown. Sternum yellowish grey. 
Table 1. Leg (I-IV) measurements (mm) in Wadicosa benadira (Caporiacco), W. cognata sp. nov., $W$. jocquei sp. nov. and W. russellsmithi sp. nov.

\begin{tabular}{|c|c|c|c|c|c|c|}
\hline & $\mathrm{Fe}$ & $\mathrm{Pt}$ & $\mathrm{Ti}$ & Mt & $\mathrm{Ta}$ & Total \\
\hline \multicolumn{7}{|c|}{ W. benadira (Caporiacco, 1940) } \\
\hline \multicolumn{7}{|l|}{ Male } \\
\hline I & 2.15 & 0.95 & 1.80 & 1.90 & 1.40 & 8.20 \\
\hline II & 2.10 & 0.90 & 1.60 & 1.85 & 1.30 & 7.75 \\
\hline III & 2.00 & 0.85 & 1.50 & 2.00 & 1.15 & 7.50 \\
\hline IV & 2.70 & 1.00 & 2.20 & 3.40 & 1.55 & 10.85 \\
\hline \multicolumn{7}{|c|}{ Female } \\
\hline I & 2.60 & 1.15 & 2.10 & 2.00 & 1.45 & 9.30 \\
\hline II & 2.50 & 1.10 & 1.90 & 1.95 & 1.35 & 8.80 \\
\hline III & 2.35 & 1.05 & 1.75 & 2.20 & 1.20 & 8.55 \\
\hline IV & 3.20 & 1.20 & 2.65 & 4.00 & 1.75 & 12.80 \\
\hline \multicolumn{7}{|c|}{ W. cognata sp. nov. } \\
\hline \multicolumn{7}{|l|}{ Male } \\
\hline I & 2.40 & 1.10 & 1.95 & 2.15 & 1.35 & 8.95 \\
\hline II & 2.30 & 1.05 & 1.70 & 2.05 & 1.20 & 8.30 \\
\hline III & 2.25 & 1.00 & 1.55 & 2.20 & 1.05 & 8.05 \\
\hline IV & 2.90 & 1.15 & 2.25 & 3.45 & 1.45 & 11.20 \\
\hline \multicolumn{7}{|c|}{ Female } \\
\hline I & 2.75 & 1.30 & 2.15 & 2.20 & 1.40 & 9.80 \\
\hline II & 2.65 & 1.25 & 1.90 & 2.10 & 1.35 & 9.25 \\
\hline III & 2.50 & 1.15 & 1.75 & 2.35 & 1.20 & 8.95 \\
\hline IV & 3.40 & 1.35 & 2.50 & 3.80 & 1.60 & 12.65 \\
\hline \multicolumn{7}{|c|}{ W. jocquei sp. nov. } \\
\hline \multicolumn{7}{|l|}{ Male } \\
\hline I & 2.30 & 1.05 & 1.90 & 2.10 & 1.40 & 8.75 \\
\hline II & 2.25 & 1.00 & 1.70 & 2.00 & 1.30 & 8.25 \\
\hline III & 2.15 & 0.95 & 1.55 & 2.20 & 1.20 & 8.05 \\
\hline IV & 2.90 & 1.10 & 2.30 & 3.60 & 1.60 & 11.50 \\
\hline \multicolumn{7}{|c|}{ Female } \\
\hline I & 2.70 & 1.25 & 2.15 & 2.15 & 1.50 & 9.75 \\
\hline II & 2.65 & 1.20 & 1.95 & 2.10 & 1.45 & 9.35 \\
\hline III & 2.50 & 1.10 & 1.85 & 2.40 & 1.35 & 9.20 \\
\hline IV & 3.40 & 1.30 & 2.75 & 4.30 & 1.85 & 13.60 \\
\hline \multicolumn{7}{|c|}{ W. russellsmithi sp. nov. } \\
\hline \multicolumn{7}{|c|}{ Female } \\
\hline I & 1.95 & 0.95 & 1.55 & 1.50 & 1.10 & 7.05 \\
\hline II & 1.90 & 0.90 & 1.40 & 1.50 & 1.05 & 6.75 \\
\hline III & 1.80 & 0.90 & 1.30 & 1.65 & 0.95 & 6.60 \\
\hline IV & 2.40 & 1.00 & 2.00 & 2.90 & 1.30 & 9.60 \\
\hline
\end{tabular}


EYES. Width of row I 50 (slightly procurved as seen from front), row II 62, row III 77, row II-III 59. Diameter of AME 12, ALE 9, PME 24, PLE 19. Distance between AME 9, between AME and ALE 2.

ABDOMEN. Dorsum blackish with pattern of yellowish spots and bars. Lanceolate stripe greyish yellowish. Three yellowish spots at each side of lanceolate stripe, one at anterior half, one at middle and one at rear end. Posterior to lanceolate stripe a series of 3-4 yellowish transverse bars. Venter light yellowish to greyish with adpressed whitish pubescence and more erect scattered light hairs (difficult to see). Spinnerets yellowish.

Legs (Table I). Yellowish brown with more or less distinct dark annulation on Ti and Mt. Fe I mostly darkened, prolaterally with prominent yellowish spot. (Fe may also be more or less darkened with lighter markings obscured: probably more aged specimens.) Ta yellow. Ti I with two retrolateral spines.

Palp (Figs 2C-D, 3A, 4A, D, 5C-D). Pt 0.45, Ti 0.45, Cy 1.10. Fe mostly darkened, Pt and Ti more or less darkened yellowish, Cy more or less dark brownish, distally yellowish. Tegular apophysis inconspicuous, largely unsclerotized, widening distally (Figs 3A, 4A). Anterior retrolateral process comparatively short (Fig. 4D). Conductor long, narrow, distally bent about $90^{\circ}$ (Fig. 5C-D). Embolus comparatively short, stout, proximally with conspicuous conical protrusion directed backwards, tip with wide concavity (Figs 2C-D, 5C-D).

Female (Kenya: WNW of Mombasa)

Total length $6.1 \mathrm{~mm}$; carapace $3.25 \mathrm{~mm}$ long, $2.35 \mathrm{~mm}$ wide.

Cephalothorax And ABdomen. Carapace greyish brown (slightly lighter than in male). Median field wide, yellowish brown (sometimes weakly discernible), with jagged edges. Lateral bands (when discernible) present as yellowish brown spots, posterior one elongated. Thoracic part richly furnished with short dark hairs; median field and lateral spots in addition with numerous adpressed light hairs. Chelicerae with dark and light hairs of varying length. Colour, pattern and hairiness of abdomen similar to those of male.

EYEs. Width of row I 58 (slightly procurved as seen from front), row II 71, row III 89, row II-III 70. Diameter of AME 14, ALE 10, PME 27, PLE 23. Distance between AME 8, between AME and ALE 2.

LEGS (Table 1). Yellowish brown with darker annulation. Fe I mostly dark with distinct yellowish brown spot prolaterally in distal half. Fe II-IV dark except for "pseudoannulation", i.e., lighter dorso-lateral spots (distally) and dorso-lateral groups of whitish hairs.

Epigyne (Figs 3D, 7A, 8A, D). Median depression longer than wide. Bottom of depression with longitudinal median ridge. Elongated deeper pit at each side of median depression. Lateral elevations with more or less sclerotized rims, protruding like two lips slightly converging rearwards. Anterior part of median depression with two well separated deep foveolae. Receptacula pear-shaped, directed forwards (Fig. 8D).

\section{Size variation}

Carapace lengths of material measured: males 2.65-2.95 mm ( $\mathrm{N}=4)$, females $2.85-3.45 \mathrm{~mm}(\mathrm{~N}=16)$.

\section{Habitat}

Collected in habitats close to water.

\section{Distribution}

Somalia, Kenya. (Roewer (1959) erroneously placed 'Gelib' in Ethiopia.) 


\author{
Wadicosa cognata sp. nov. \\ urn:1sid:zoobank.org:act:18D4AAA2-7861-4AE8-A820-482BB97CB3B1 \\ Figs 1E-F, 3B, E, 4B, E, 5A, 6A-B, 7B, 8B, E, 9; Table 1
}

\title{
Diagnosis
}

The male is characterized by an embolus bent over the upper branch of the tegular apophysis (Fig. 3B), similar to that in $W$. fidelis but differing from the latter by the apicalmost part of the embolus being considerably narrower ( $c f$. Fig. 5A-B). The female has an epigyne with a configuration resembling that in W. fidelis, but differing from the latter by its proportions ( $c f$. Fig. 3E-F).

\section{Etymology}

The specific epithet means 'having affinity with', referring to the similarity of this species with W. fidelis.

\section{Material examined}

\section{Holotype}

KENYA: ${ }^{\top}$, Kajiado, Lake Magadi, station 3, $600 \mathrm{~m}$ asl, 1.850 S, $36.217^{\circ}$ E, 31 Jan. 1999, station 3, S.E. Miller \& T.M. Kuklenski (NMKE).

\section{Paratypes}

KENYA: Kajiado, same data as for holotype, 1 (allotype, NMKE); Lake Magadi, running over surface of hypersaline pool, $1^{\circ} 52.7^{\prime} \mathrm{S}, 36^{\circ} 15.7^{\prime} \mathrm{E}, 4$ Oct. 1998, G.M. Nishida, 1 ㅅ, 3 우 (MRAC 208378, except 1 i in BPBM); station 4, $600 \mathrm{~m}$ asl, $1.866^{\circ} \mathrm{S}, 36.266^{\circ} \mathrm{E}, 31$ Jan. 1999, S.E. Miller \& T.M. Kuklenski, 1 Oे, 1 q (USNM); station 3, $600 \mathrm{~m}$ asl, 1.850 ${ }^{\circ}$ S, $36.217^{\circ}$ E, 31 Jan. 1999, S.E. Miller \& T.M. Kuklenski, 1 ô, 4 우 (BMNH, except 1 ㅇ in NHRS).

\section{Description}

Male (holotype)

Total length 5.8. Carapace 3.15 long, 2.30 wide.

Cephalothorax. Carapace greyish brown. Median field in thoracic part sometimes lighter to yellowish grey, wide around fovea, edges of light field jagged but indistinct. Lateral bands absent or present as separate, indistinct, slightly lighter spots. An elongate lighter spot may be visible on each side at level of coxae III-IV; this spot as well as adjacent part of carapace margin densely furnished with whitish hairs. Thoracic part furnished with short dark hairs and recumbent light hairs, latter numerous in median field (though often worn off). Clypeus dark greyish brown with dark hairs. Chelicerae greyish brown with dark hairs. Sternum greyish yellow with erect dark hairs.

EYES. Width of row I 53 (slightly procurved as seen from front), row II 76, row III 94, row II-III 76. Diameter of AME 13, ALE 10, PME 30, PLE 24. Distance between AME 8, between AME and ALE 2.

ABDOMEN. Dorsally dark brownish grey with indistinct, somewhat lighter brownish grey lanceolate stripe. Dorsum covered with numerous long erect dark hairs, short dark hairs, and recumbent light hairs. No distinct pattern. Venter greyish yellow to light greyish with dense light pubescence and scattered erect dark hairs. Spinnerets greyish yellow.

LEGS (Table 1). Greyish yellow with moderately darker annulation throughout.

Palp (Figs 3B, 4B, E, 5A, 6A-B). Pt 0.55 , Ti 0.55 , Cy 1.35 . Fe greyish brown, apically light yellow. Pt and Ti light yellow dorsally. Cy light yellowish basally, otherwise greyish brown, lighter distally. Palp with dark hairs, light yellowish parts with dense white pubescence. Tegular apophysis with comparatively 
long upper branch (Fig. 6A), directed retrolaterad and slightly bent posteriad. Shorter lower branch weakly sclerotized, outer portion partly covered with numerous minute spinulae and underlying portion with verrucose outgrowths (Fig. 6A), the latter (Fig. 6B) of varying density and length (cf. Figs 4B, 6A). For differences between $W$. cognata and $W$. fidelis in shape of verrucose outgrowths $c f$. Fig. 6B, D. Tegulum proximally with heavily sclerotized, low cristate posterior retrolateral process, and distally with long anterior retrolateral process directed ventrad; in between a shallow depression, here called scutra (Latin sing.: flat dish; termed 'pyriform depression' in Kronestedt \& Zyuzin 2009; ventral view: Fig. 4B; retrolateral view: Fig. 4E). Embolus long, forming conspicuous bend over upper branch of tegular apophysis, apical part only slightly widened (Fig. 5A, cf. W. fidelis: Fig. 5B).

Female (Kenya: Lake Magadi)

Total length 7.1. Carapace 3.60 long, 2.80 wide.

Cephalothorax and abdomen. As in male though median field of carapace hardly discernible. Abdomen patterned, when visible, similar to $W$. benadira (vide supra).
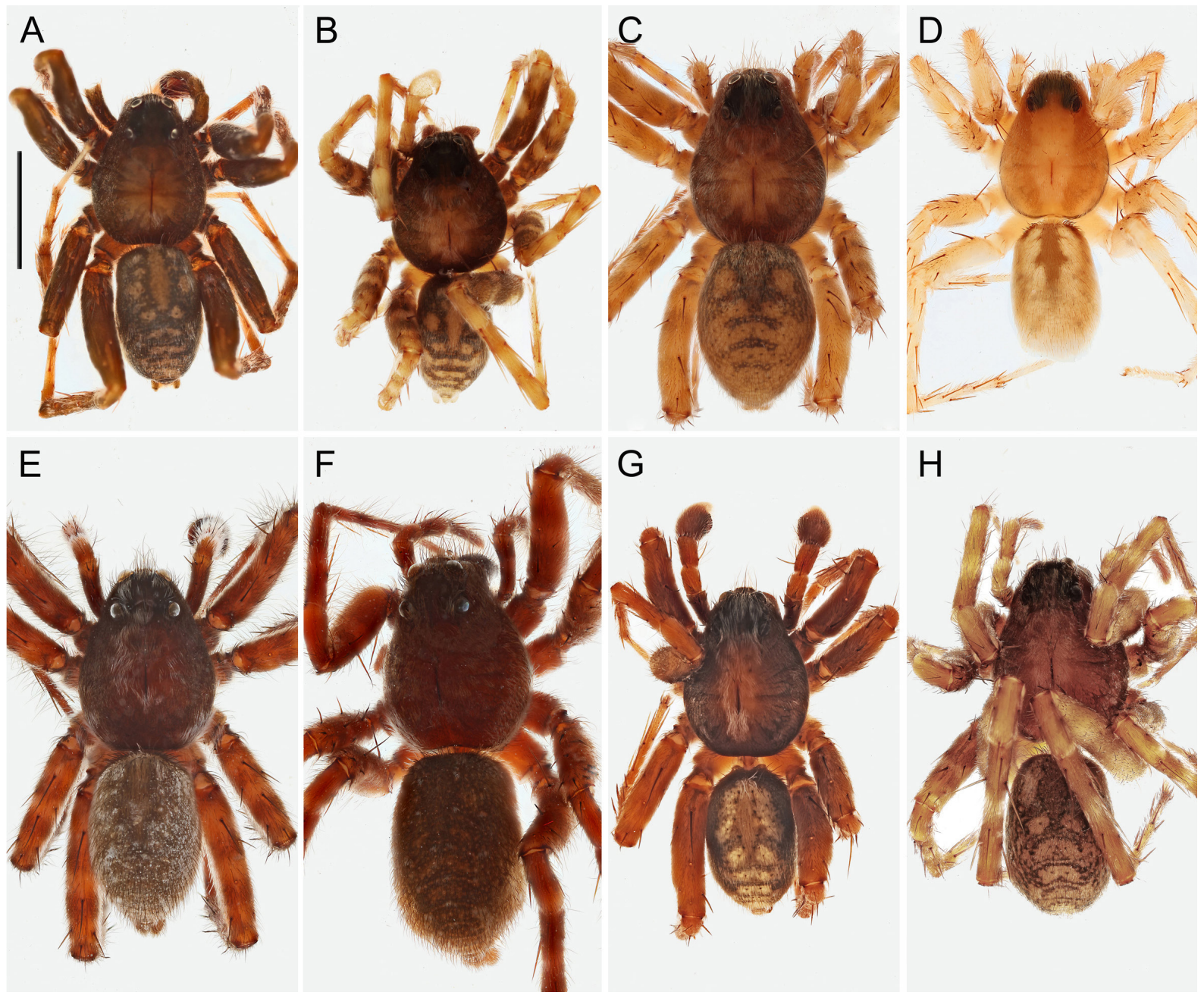

Fig. 1. Habitus, dorsal view. - A-C. Wadicosa benadira (Caporiacco). A $ð$ from Kenya, Marsabit. $\mathrm{B} \hat{\jmath}$ and $\mathrm{C} q$ from Kenya, WNW of Mombasa. - D. W. russellsmithi sp. nov., holotype, $q .-\mathbf{E}-\mathbf{F}$. W. cognata sp. nov. E $\delta$ and $\mathrm{F}+$ from Kenya, Lake Magadi. - G-H. W. jocquei sp. nov. G ô from Comoros, Pomoni. $\mathrm{H}+$ from Mayotte. Scale bar: $\mathrm{A}-\mathrm{H}=2 \mathrm{~mm}$. 
EYES. Width of row I 61 (slightly procurved as seen from front), row II 83, row III 107, row II-III 80. Diameter of AME 14, ALE 10, PME 30, PLE 27. Distance between AME 10, between AME and ALE 2.

LEGS (Table 1). As in male.

Epigyne (Figs 3E, 7B, 8B, E). Epigynal cavity much wider than long, bottom corrugated. Median septum short, wrinkled. Median depression in front of septum distinct, bordered by lateral elevations. Foveolae of varying width, rounded to narrow, partly confluent, sometimes in part hidden by protruding rims of lateral elevations (Fig. 8B, arrow). Spermathecae large, somewhat spherical, directed towards mid-line of venter (Fig. 8E).

\section{Size variation}

Carapace lengths of material measured: males 3.15-3.40 $(\mathrm{N}=4)$, females $3.50-4.00(\mathrm{~N}=8)$.

\section{Habitat}

The type locality is a hypersaline (sodium carbonate) lake.

\section{Distribution}

Only known from Kenya. Most probably occurring also in the Tanzanian part of the Magadi-Natron Basin.

Wadicosa jocquei sp. nov. urn:1sid:zoobank.org:act:72E7DB23-929F-4553-8FEC-51BABA5D723C

Figs 1G-H, 2E-F, 3C, G, 4C, F, 5E, 7C, 8C, F, 9; Table 1

\section{Diagnosis}

The male palp is characterized by having a small terminal part carrying a non-pigmented pointed conductor and a stout and smoothly tapering embolus, slightly curved, running transversally over most of the bulbus. The female differs from other Wadicosa species by having an epigyne with deep median cavity wider than long, its posterior rim somewhat protruding.

\section{Etymology}

The specific epithet is a patronym in honour of Dr Rudy Jocqué, an authority on African spiders who first enabled me to study material of this species.

\section{Material examined}

\section{Holotype}

COMOROS: Ō, Anjouan, Pomoni, $12^{\circ} 17^{\prime}$ S, 44²4’ E, marsh locality, low vegetation, 5 Dec. 1983, R. Jocqué (MRAC 244077).

\section{Paratypes}

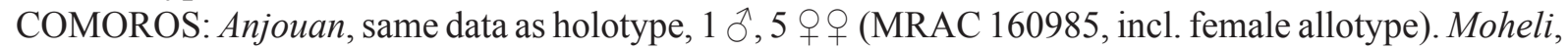

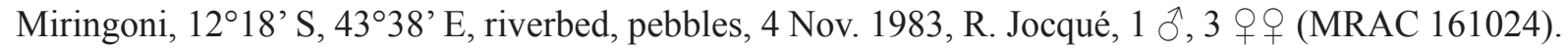

MAYOTTE (France): Petit Terre, Dziani Dzaha, 1246’ S, 45¹7’ E, 19 Feb. 1999, R. Jocqué \& G. De

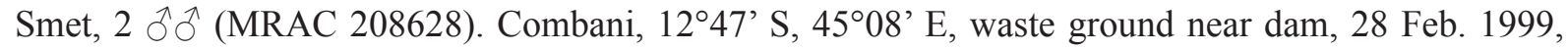
R. Jocqué \& G. De Smet, 3 ồ $\widehat{\partial}, 2$ 우 (MRAC 208507). 


\section{Other material examined}

MADAGASCAR: Alaotra-Mangoro, Lac Alaotra, 17³0' S, 48³0' E, river, yellow tray, 22 Apr. 1992,

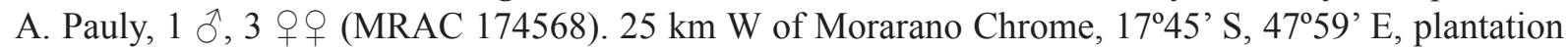
in forest, yellow tray, 10-25 May 1991, A. Pauly, 3 우우 (MRAC 174365). Atsinanana, Mahavelona

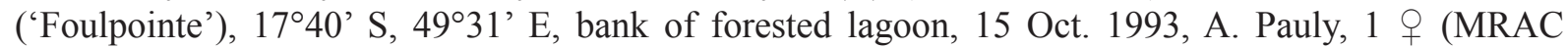
177757); forest with sandy soil, Aug. 1994, A. Pauly, 14 우 우 (MRAC 201838, except 2 우우 in NHRS); forested lagoon, along bank of channel, Oct. 1994, A. Pauly, 1 O , 1 ㅇ (MRAC 201728); Analalava Forest, yellow tray, Jan. 1995, A. Pauly, $11 \hat{\partial} \widehat{\partial}, 1$ क (MRAC 206755, except $2 \hat{\jmath} \widehat{\partial}$ in NHRS); Analalava Forest, Feb. 1995, A. Pauly, 14 đ̊ $\widehat{~(M R A C ~ 206538) ; ~ f o r e s t ~ o n ~ c l a y e y ~ s o i l, ~ s i e v i n g ~ l e a f ~ l i t t e r, ~ A u g . ~ 1995, ~}$

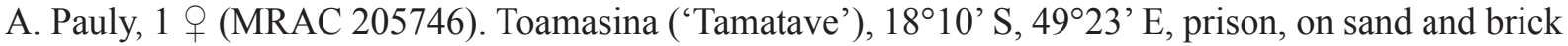
wall, Jul. 1994, A. Pauly, 1 đ̂, 1 ㅇ (MRAC 201739). Atsino-Andrefana, Tulear, Aug. 1967, J. Picard, 2 우우 (MRAC 133738, 133739); Mahafaly, near Eloetse, by Lake Tsimanampetsoa, $24^{\circ} 10^{\prime}$ S, $43^{\circ} 45^{\prime}$ E, 15-16 Sep. 1992, V. \& B. Roth, 1 \& (CAS-ENT 9008637).

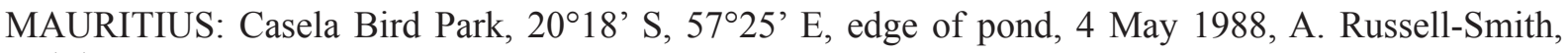

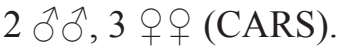

SEYCHELLES: Aldabra, Malabar, 9²2’ S, 46²3’ E, 1970, G. Hamadion, 1 đ̊, 1 q (MRAC 141122).

\section{Description}

Male (holotype)

Total length $5.3 \mathrm{~mm}$; carapace $3.00 \mathrm{~mm}$ long, $2.20 \mathrm{~mm}$ wide.
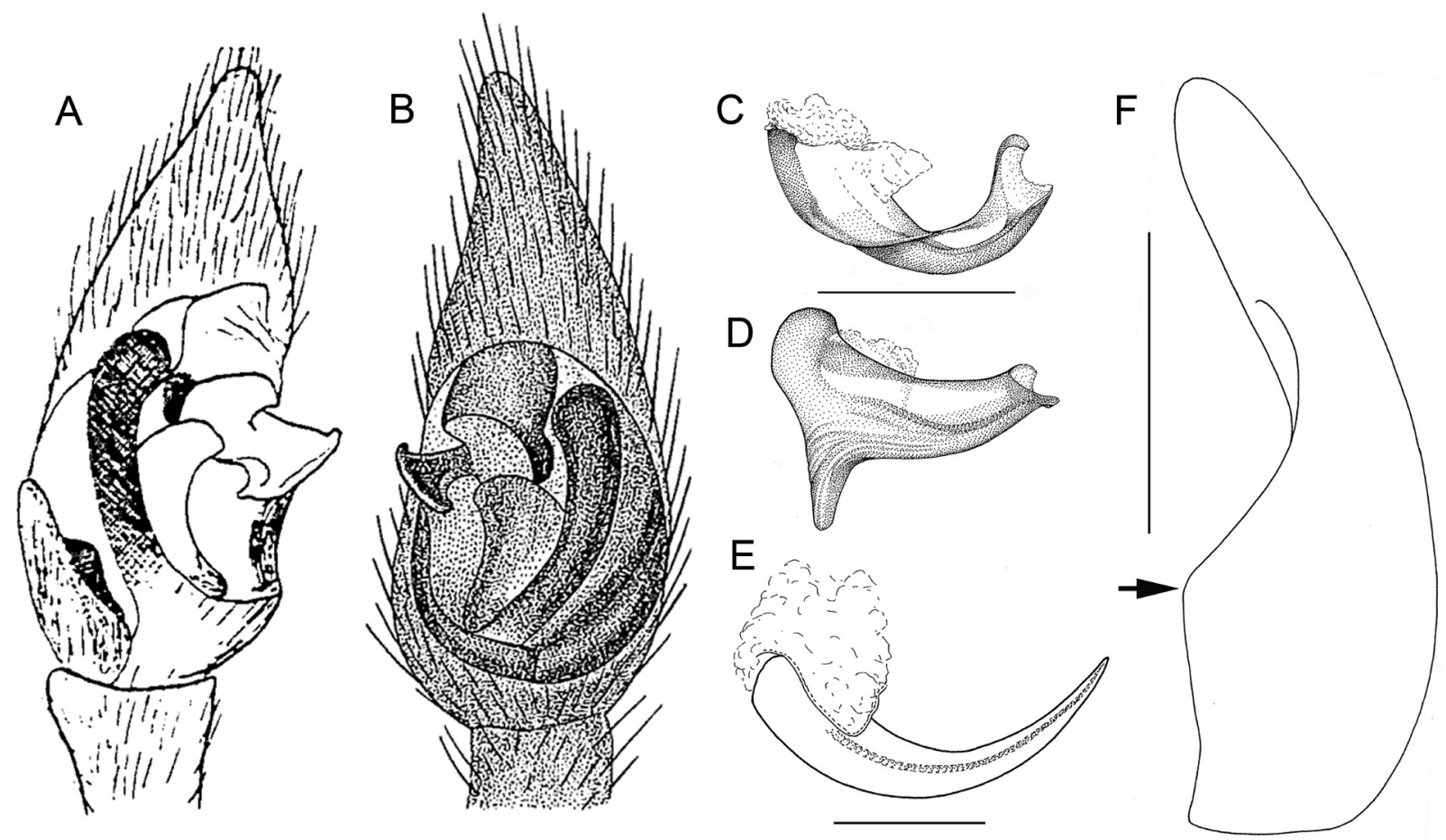

Fig. 2. - A-D. Wadicosa benadira (Caporiacco). A. Left male palp, from Caporiacco (1940: fig. 1). B. Right male palp, from Roewer (1959: fig. 18). C-D. Left embolus in $\widehat{\delta}$ from Kenya, Marsabit; anterior (C) and ventral (D) view. - E-F. W. jocquei sp. nov. Left embolus (E), frontal view, and left cymbium (F) in $\delta$ from Comoros, Anjouan. Arrow points at projecting retrolateral rim of cymbium. Scale bars: $\mathrm{C}-\mathrm{E}=0.2 \mathrm{~mm}, \mathrm{~F}=0.5 \mathrm{~mm}$. 
Cephalothorax. Carapace sooty yellowish with more or less distinct, wide, greyish yellow median band. Lateral bands faint or missing. Sides of thoracic part with short, black recumbent hairs, median band in addition with dense pubescence of adpressed light hairs (often more or less abraded). Clypeus sooty, more yellowish laterally. Chelicerae yellowish, with sooty elongate markings. Sternum greyish yellow.
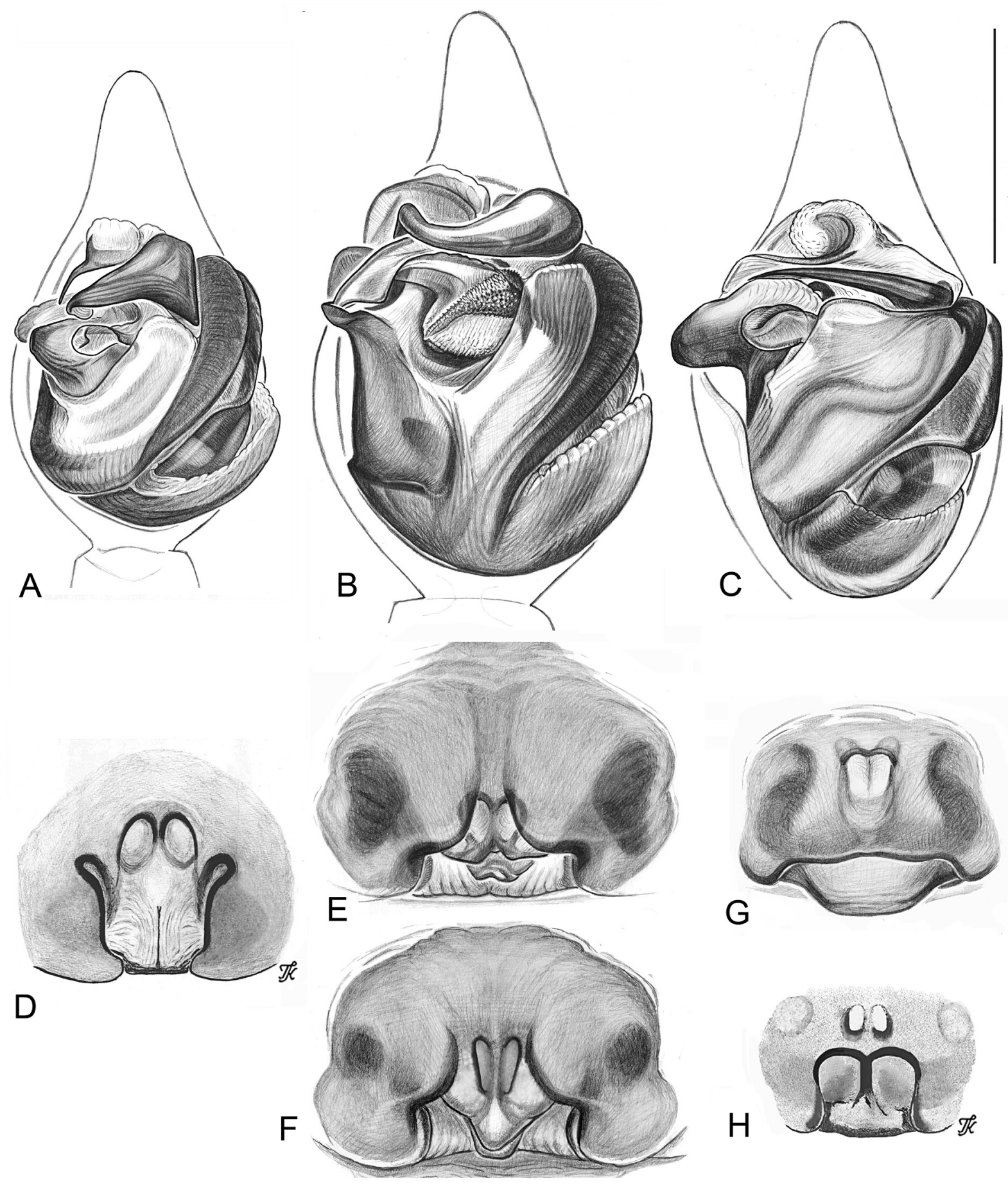

Fig. 3. Right male palp, ventral view (A-C) and epigyne (D-H). - A, D. Wadicosa benadira (Caporiacco) (A from Kenya, WNW of Mombasa; D from Kenya, Marsabit). - B, E. W. cognata sp. nov. B. Holotype. E. Paratype. - C, G. W. jocquei sp. nov. C. Holotype. G. Allotype. - F. W. fidelis (Pickard-Cambridge) from Spain. - H. W. russellsmithi sp. nov., holotype. Scale bar: A-H $=0.5 \mathrm{~mm}$. 
EYES. Width of row I 49 (lower tangential line very slightly procurved, upper tangential line distinctly procurved as seen from front), row II 65, row III 82, row II-III 65. Diameter of AME 12, ALE 9, PME 25, PLE 20. Distance between AME 9, between AME and ALE 2.

ABDOMEN. Dorsum blackish with pattern of yellowish spots. Lanceolate stripe yellowish grey, bordered in black. Yellowish spots along each side of lanceolate stripe, anterior spots sometimes confluent, posterior one separate. Posterior to lanceolate stripe a series of paired yellowish, more or less confluent spots alternating with transverse blackish bars. Each spot with blackish median dot. Venter more or less light yellowish grey, with white adpressed pubescence and scattered more erect short dark hairs. Spinnerets yellowish grey.
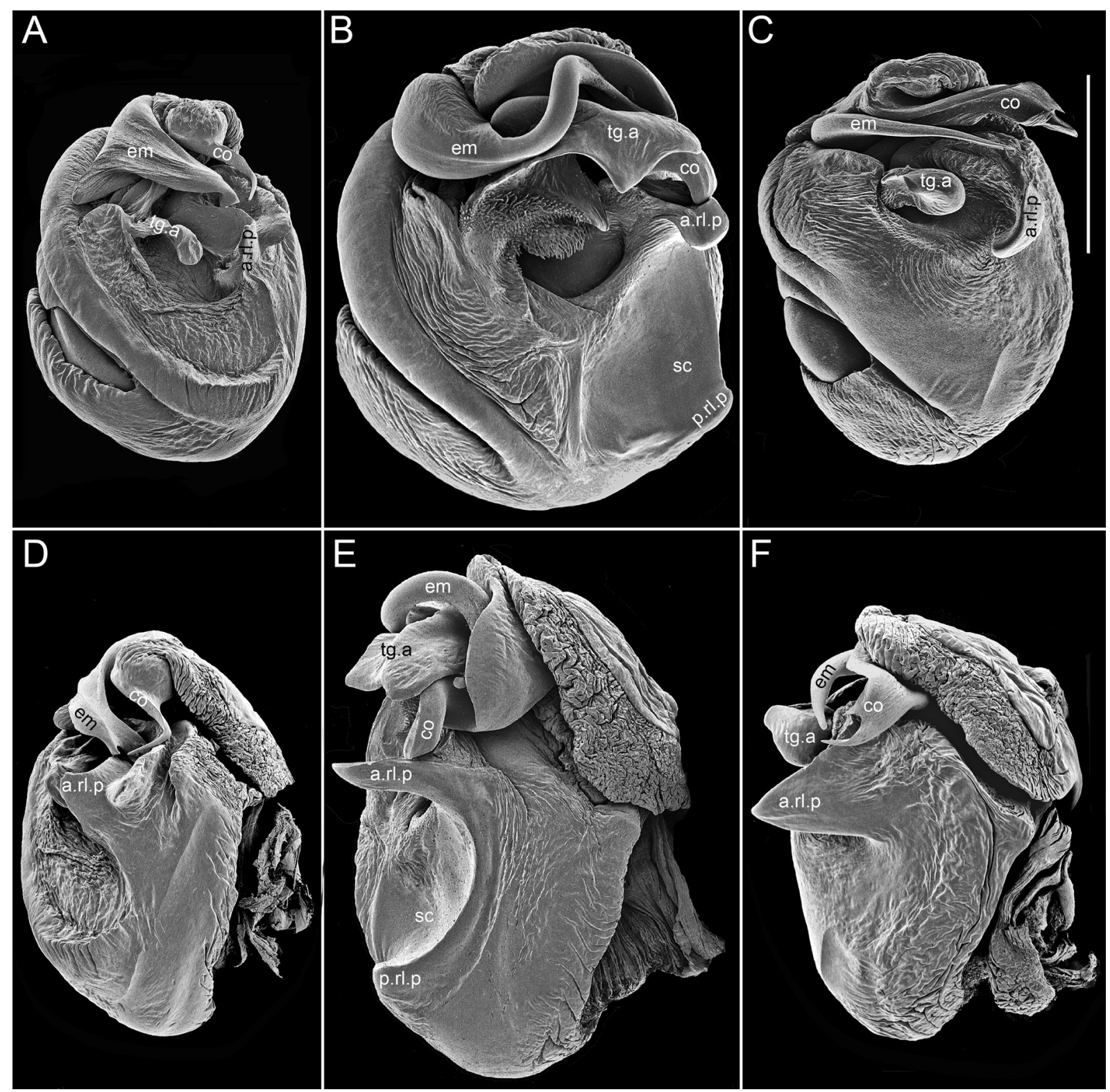

Fig. 4. Bulbus of left male palp in ventral (A-C) and retrolateral (D-F) view. - A, D. Wadicosa benadira (Caporiacco), from Kenya, WNW of Mombasa. - B, E. W. cognata sp. nov., from Kenya, Lake Magadi. - C, F. W. jocquei sp. nov., from Comoros, Moheli. a.rl.p, anterior retrolateral process; co, conductor; em, embolus; p.rl.p, posterior retrolateral process; sc, scutra; tg.a, tegular apophysis. Scale bar: $\mathrm{A}-\mathrm{F}=300 \mu \mathrm{m}$. 
Legs (Table 1). Yellowish, with weak sooty annulations, Fe more or less sooty, with lighter "pseudoannulation" and various markings.

Palp (Figs 2E-F, 3D, 4C, F, 5E). Pt 0.55, Ti 0.55, Cy 1.30. Yellowish brown with more (aged individuals?) or less sooty markings. Cy yellowish distally, otherwise yellowish brown; apically with narrow spine (occasionally missing). Retrolateral rim of Cy projecting (Fig. 2F, arrow). Tegular apophysis inconspicuous, largely unsclerotized, distal half widened, rounded, with protrusion, having blackened rim, pointing ventrad. Anterior retrolateral process well developed (Fig. 4F). Terminal part with transverse conductor, partly transparent, distally with transparent projections and ending in a somewhat darkened, slightly curved pointed tip (Figs 4C, F, 5E). Embolus comparatively long and stout (sclerotized), slightly curved in ventral view (more curved in frontal view), and smoothly tapering to tip (Figs 2E, 4C, F, 5E).

Female (allotype)

Total length $6.3 \mathrm{~mm}$; carapace $3.40 \mathrm{~mm}$ long, $2.60 \mathrm{~mm}$ wide.

Cephalothorax. Carapace dark brownish with indistinct, wide, yellow-brown median band and broken lateral bands (sometimes faint).

EYES. Width of row I 58 (slightly procurved as seen from front), row II 78, row III 98, row II-III 77. Diameter of AME 14, ALE 10, PME 28, PLE 23. Distance between AME 9, between AME and ALE 2.

AвDOMEn. Dorsally and laterally patterned in black and yellow, similar to male.
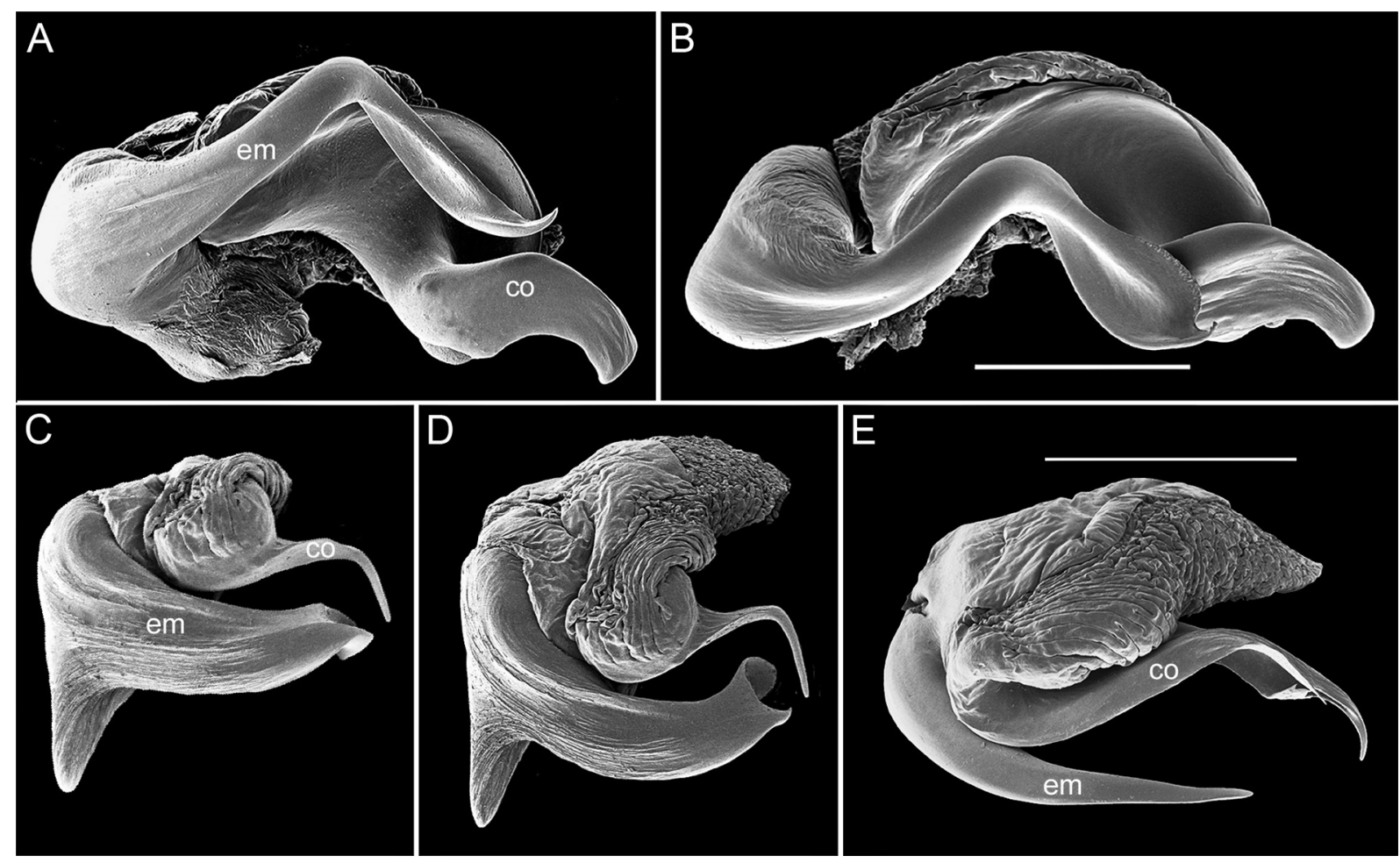

Fig. 5. Terminal part of left male palp with embolus (em) and conductor (co). - A. Wadicosa cognata sp. nov., from Kenya, Lake Magadi, ventral view. - B. W. fidelis (Pickard-Cambridge), from Spain, ventral view. - C-D. W. benadira (Caporiacco), from Kenya, WNW of Mombasa. C. Ventral view. D. More frontal view. - E. W. jocquei sp. nov., from Comoros, Moheli, frontal view. Scale bars: A-B $=200 \mu \mathrm{m}, \mathrm{C}-\mathrm{E}=200 \mu \mathrm{m}$. 
Legs (Table 1). Brownish yellow with darker annulation.

Epigyne (Figs 3G, 7C, 8C, F). Median cavity wider than long, with posterior rim rounded, more or less protruding. Anterior part of epigyne with two close, partly confluent foveolae. Receptacula rounded (Fig. 8F), when heavily sclerotized visible through the integument. In several examined females, median cavity covered with amorphous stiff substance (probably serving as mating plug) (cf. Kronestedt 1987; Uhl et al. 2010).

\section{Size variation}

Carapace lengths of material measured: males $2.60-3.10 \mathrm{~mm}(\mathrm{~N}=10)$, females $2.95-3.70 \mathrm{~mm}(\mathrm{~N}=20)$.

\section{Remarks}

The male from Aldabra differs by the proportions of the cymbium, the apical part being relatively short, although the configuration of the bulbus corresponds to that of the other males.
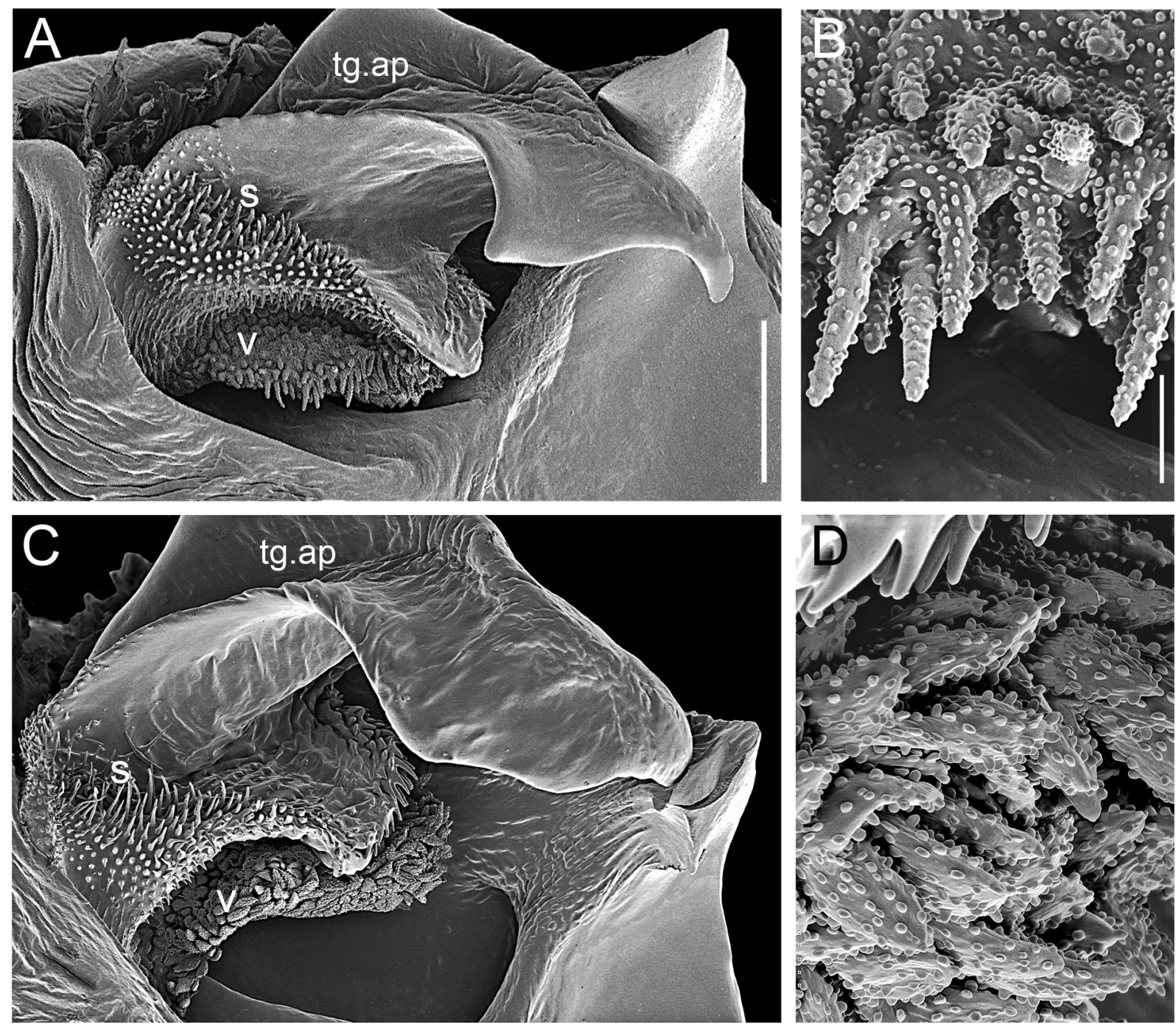

Fig. 6. Tegulum of left male palp with tegular apophysis (tg.a). Basal part and lower branch of tegular apophysis with spinulae $(s)$ and verrucose outgrows $(v)$, the latter enlarged in B and D. - A-B. Wadicosa cognata sp. nov., from Kenya, Lake Magadi. - C-D. W. fidelis (Pickard-Cambridge), from Spain. Scale bars: A, C $=100 \mu \mathrm{m}, \mathrm{B}, \mathrm{D}=10 \mu \mathrm{m}$. 
Several specimens from Foulpointe have an overall darker colour than the rest of the material studied.

A male from Ethiopia (Gamo Gofa, 49 km SE of Sodo, 19 Aug. 1997, W.J. Pulawski, CAS-ENT 9046030), of a presumably undescribed species, has a bulbus morphologically resembling that in W. jocquei sp. nov. but differs inter alia in the shape of the embolus (shorter and broader).

\section{Habitat}

The species seems to prefer sites close to water.

\section{Distribution}

Seychelles (Aldabra), Comoro Islands (Anjouan, Mohéli, Mayotte), Madagascar, Mauritius (Fig. 9). This is the first lycosid species to be reported from Aldabra. Bristowiella seychellensis (Bristowe, 1973) was erroneously reported as occurring there (Saaristo 2010; El-Hennawy 2011), although it has been found on several islands in the Seychelles and on the three large islands of the Comoros (Alderweireldt 1988; Saaristo 2010), as well as on Madagascar (material in MRAC).

Wadicosa oncka (Lawrence, 1927) comb. nov.

Pardosa oncka Lawrence, 1927: 51, pl. 2, fig. 39 (ㅇ). — Kronestedt 1987: 967, figs 1-6 (ð゚o+), with synonymies.

Material examined (from countries without previously published records)

BURKINA FASO: Ouagadougou, $12^{\circ} 22^{\prime} \mathrm{N}, 1^{\circ} 31^{\prime} \mathrm{W}$, pitfall in riverine forest, Apr--May 1965, B. Roman, 2 우 (MRAC 128081).

GABON: Port Gentil, 043’ S, 846’ E, 12 Jul. 1957, E.S. Ross \& R.E. Leech, 1 q (CAS-ENT 9046042).

MALAWI: Northern Region, Nyika Plateau, 1040’ S, 335’' E, Chowo-rocks, 2150 m, 6-18 Dec. 1981, R. Jocqué, 1 + (MRAC 170725).

NIGER: Tillabéri, Malalé, $10 \mathrm{~km}$ E of Niamey, 13⒉1' N, 2º10.4' E, 4 Aug. 2005, M. Garba \& W.J. Pulawski, 2 ô ô (CAS-ENT 9046056).

RWANDA: Gisenyi, $1^{\circ} 42^{\prime}$ S, 29¹6’ E, shore of Lake Kivu, 11 Dec. 1985, Jocqué, Nsengimana \& Michiels, 1 ô, 1 ㅇ (MRAC 172726, 172727).

SIERRA LEONE: Freetown, $8^{\circ} 30^{\prime}$ N, $13^{\circ} 15^{\prime}$ W, Botanical Garden, Apr.-May 1977, D. Olu-Pitt, 2 q $q$ (MRAC 159111).

ZIMBABWE: Matabeleland North, Batika Gorge \& Dibu Dibu River, 1758' S, 255'ㄹ E, 27-28 Oct. 1990, V.D. \& B. Roth, 1 ô, 1 q (CAS-ENT 9046045, 9046051).

\section{Remarks}

Pardosa oncka Lawrence, 1927 is here formally placed in Wadicosa. This species, with a wide distribution in Africa south of the Sahara, was redescribed in detail by Kronestedt (1987), who emphasized the presence of characters diagnostic for the genus Wadicosa. The combination Wadicosa oncka was used in Dippenaar-Schoeman \& Jocqué (1997) and subsequently, e.g., in Oyediran et al. (2000). This combination has not been formally accepted in the World Spider Catalog (2015). 


\section{Distribution}

Angola, Botswana, Cameroon, Democratic Republic of the Congo, Ethiopia, Ivory Coast, Kenya, Mozambique, Namibia, Nigeria, South Africa, Tanzania, Zambia (Kronestedt 1987), Sudan (Siyam et al. 2015), Burkina Faso, Gabon, Malawi, Niger, Rwanda, Sierra Leone, Zimbabwe.

Wadicosa russellsmithi sp. nov.

urn:1sid:zoobank.org:act:4F5449E0-F250-4FC1-AA4E-EE048835E986

Figs 1D, 3H, 7D; Table 1

\section{Diagnosis}

The female is distinguished from other Wadicosa species by the epigyne having a median cavity, divided in front by a septum.
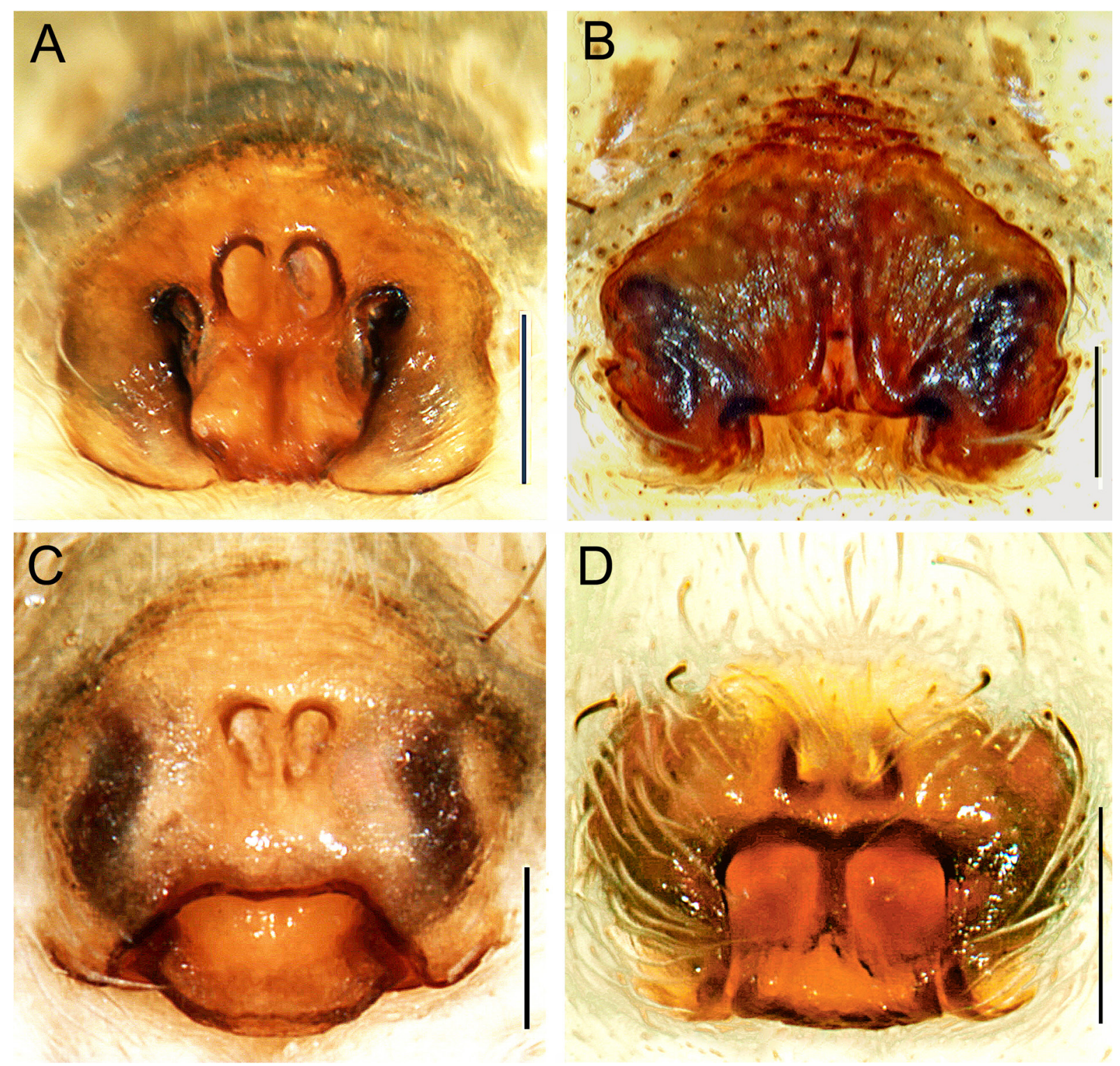

Fig. 7. Epigyne, ventral view. - A. Wadicosa benadira (Caporiacco), from Kenya, Tsavo East NP. B. W. cognata sp. nov., allotype. - C. W. jocquei sp. nov., from Madagascar, Mahafaly. - D. W. russellsmithi sp. nov., holotype. Scale bars $=0.2 \mathrm{~mm}$. 


\section{Etymology}

This species is named for the British arachnologist Dr Anthony Russell-Smith, collector of the specimen, who also in different ways has contributed to an increased knowledge of the Afrotropical spider fauna.

\section{Material examined}

\section{Holotype}

MAURITIUS: + , Casela Bird Park, $20^{\circ} 18^{\prime}$ S, $57^{\circ} 25^{\prime}$ E, edge of pond, 4 May 1988, A. Russell-Smith (BMNH).

\section{Description}

Female (holotype)

Total length 5.3. Carapace 2.70 long, 2.00 wide.

Cephalothorax. Carapace light brown with wide yellowish brown median band. Lateral bands yellowish brown and carapacal margin black. Clypeus yellowish. Chelicerae light brown. Sternum yellowish, slightly suffused with grey.

EyEs. Width of row I 47, row II 64, row III 81, row II-III 62. Diameter of AME 11, ALE 9, PME 24, PLE 21. Distance between AME 8, between AME and ALE 2.

AвDOMEn. Dorsally whitish brown with greyish lanceolate stripe (for shape see Fig. 1D). Anteriorly at each side of lanceolate stripe a dark greyish spot. Sides with light greyish streaks. (Posteriormost part
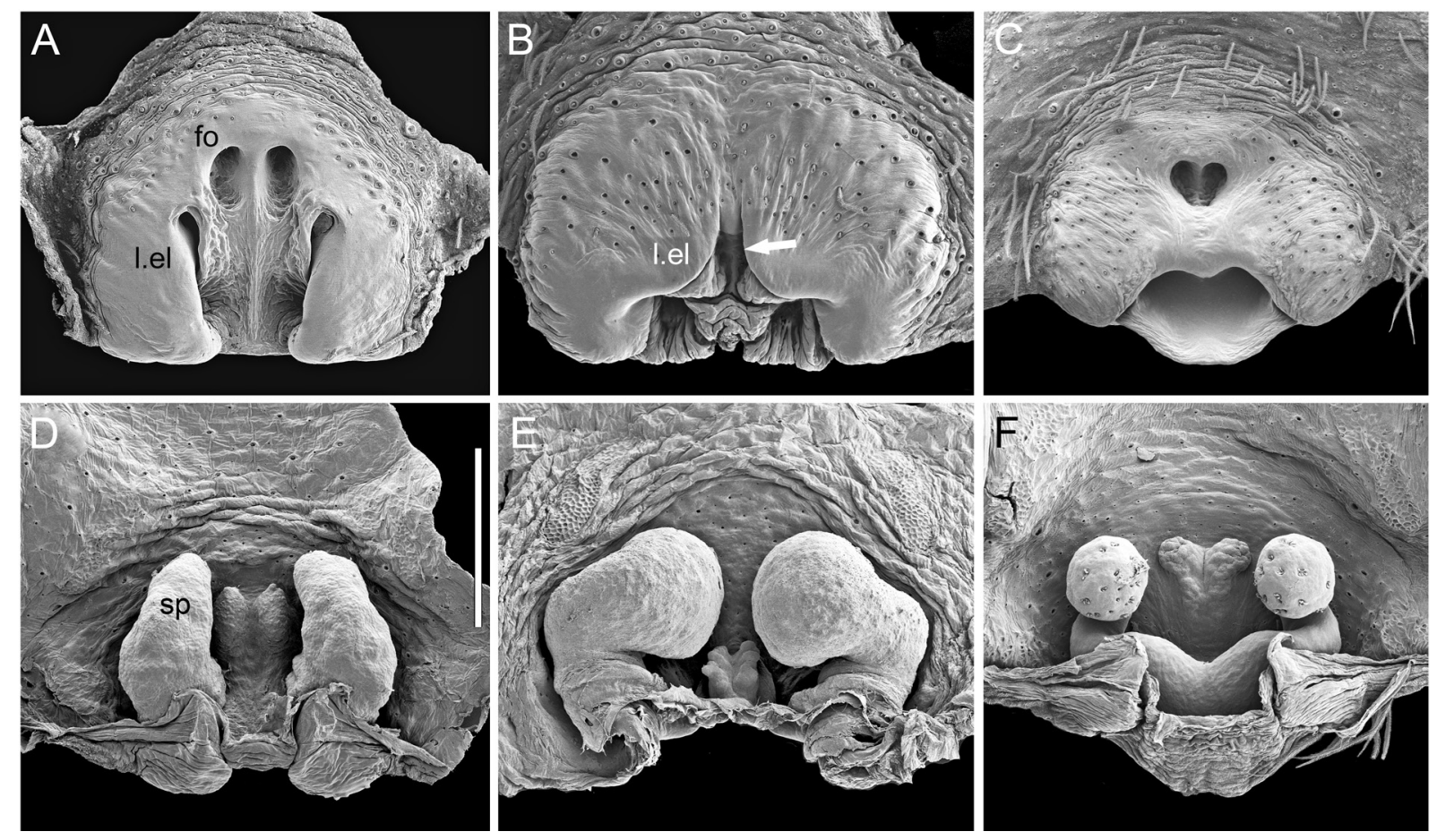

Fig. 8. Epigyne in ventral (A-C) and dorsal (D-F) view. - A, D. Wadicosa benadira (Caporiacco), from Kenya, Marsabit. - B, E. W. cognata sp. nov., from Kenya, Lake Magadi. - C, F. W. jocquei sp. nov. C. From Mauritius. F. From Comoros, Anjouan. fo, foveola; l.el. lateral elevation; $s p$, spermatheca; arrow points at lateral elevation partly covering foveola. Scale bars: A-F $=300 \mu \mathrm{m}$. 
of abdomen missing in holotype.) Venter whitish with adpressed white pubescence and scattered short greyish hairs.

Legs (Table 1). Yellowish with darker greyish longitudinal marks pro- and retrolaterally on all femora. Ti I with distal retrolateral spine.

EpIGYNe (Figs 3H, 7D). Foveolae separate, situated at some distance in front of cavity, the latter wider than long, divided in front by median septum.

\section{Remarks}

This species is placed in Wadicosa due to the presence of two foveolae in the epigyne. The placement is made with hesitation as no male has yet been found. It is hoped that this description will stimulate the search for more material of this species on Mauritius. The single specimen has a notably pale appearance.

\section{Distribution}

Mauritius.

\section{Discussion}

The generic placement of the five species treated above in the genus Wadicosa is tentative. Until more species of this genus are sufficiently described, the concept of the genus is taken in a broad sense, equivalent to the subfamily Wadicosinae. When introducing this subfamily, Zyuzin (1985) did not give any diagnosis for it per se, just a description of the new genus Wadicosa (emended diagnosis in

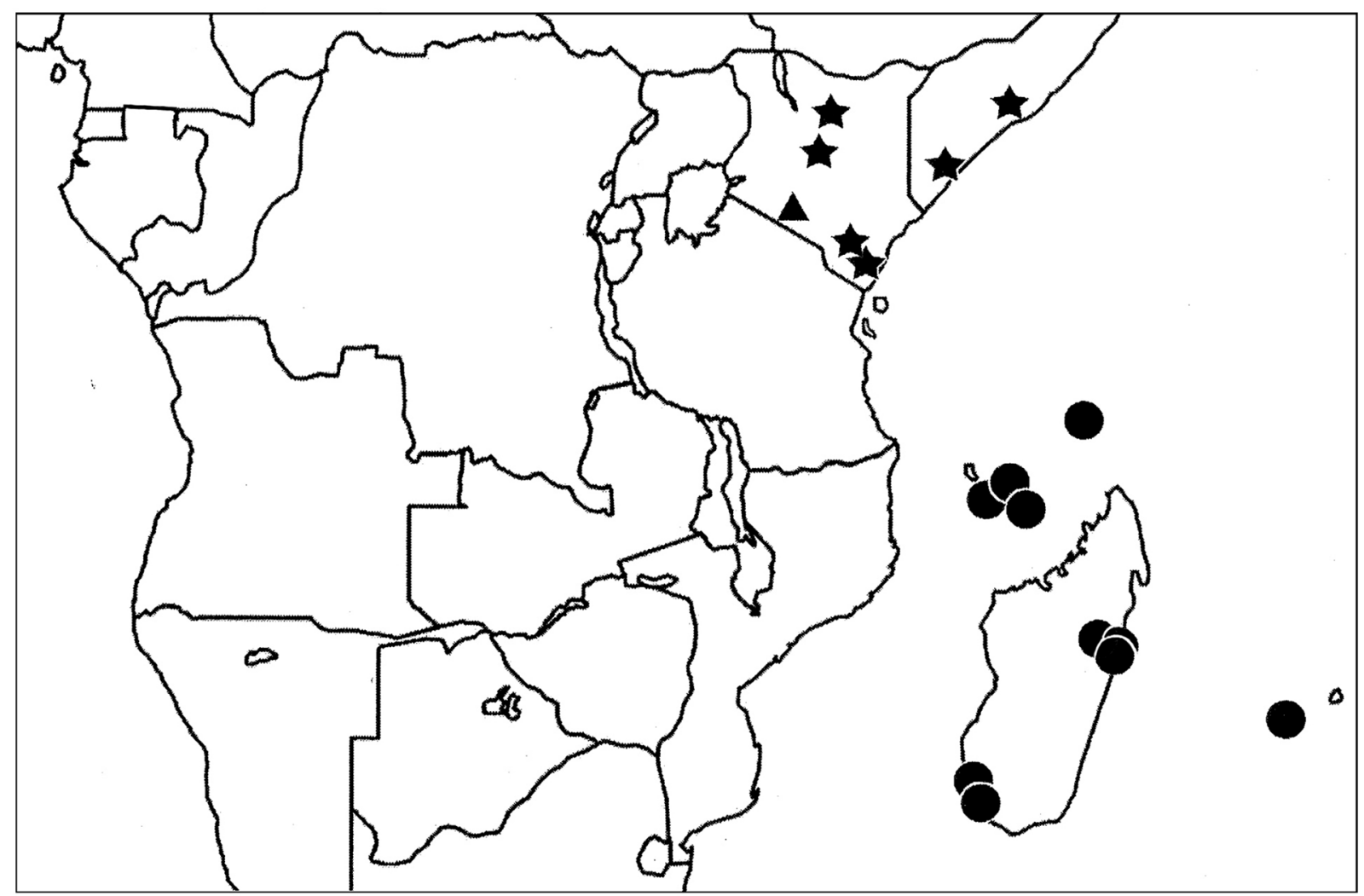

Fig. 9. Collection localities for Wadicosa benadira (Caporiacco) (stars), W. cognata sp. nov. (triangle) and $W$. jocquei sp. nov. (circles). One symbol may refer to more than one locality. 
Kronestedt \& Zyuzin 2009). Molecular studies (16S rRNA) have placed Wadicosa within the genus Pardosa and, accordingly, the subfamilial level has been put in question (Yan \& Yan 2007).

It is evident that this genus will be split on morphological grounds in the future. Among the species treated here, $W$. jocquei sp. nov., $W$. oncka and $W$. russellsmithi sp. nov. stand out as strongly different from the type species, W. fidelis, in a number of characteristics (e.g., overall configuration of bulbus, shape of embolus and tegular apophysis, configuration of epigyne).

On the other hand, $W$. cognata sp. nov. shows comparatively small morphological differences from $W$. fidelis, with which it shares the configuration of the bulbus, inter alia the shape of the tegular apophysis, the conductor and the embolus, as well as the presence of a posterior retrolateral process and a scutra, and the configuration of the epigyne ( $c f$. Kronestedt \& Zyuzin 2009). Also, both spinulae and verrucose outgrows (function unknown) on the tegular apophysis, first described in Kronestedt \& Zyuzin (2009), are present in both species. These two species constitute a group, the Wadicosa fidelis group, to which also some Asian species can be assigned on morphological grounds (e.g., configuration of embolus), including W. commoventa, W. daliensis (Yin et al. 1997), W. okinawensis and Wadicosa sp. from Borneo (Zehethofer 1998).

\section{Acknowledgements}

I am indebted to Dr Charles Griswold, Mr Darrell Ubick and Ms Anthea Carmichael (CAS), Dr Rudy Jocqué (MRAC), Dr Anthony Russell-Smith, Sittingbourne, Kent, U.K. and Ms Sarah Whitman (MZUF) for loan of material, and to Dr Scott Miller (USNM) for sending material collected by him and collaborators. I also want to acknowledge the help from Dr Mark Alderweireldt, Ghent and Dr RussellSmith for preliminary identification of material to Wadicosa or Wadicosinae in MRAC and MRAC \& CAS, respectively. My thanks to Dr Jocqué for comments on the manuscript and to the Jocqué family for their hospitality during my stay in Tervuren in 1991. Thanks also to Ms Andrea Klintbjer (Fig. 3A-C, E-G) and Ms Elisabeth Binkiewicz (Fig. 2C-F) for their skilful drawings.

\section{References}

Alderweireldt M. 1988. On the genus Bristowiella, with the description of B. kartalensis n. sp. from the Comoro Islands (Araneae, Lycosidae). Bulletin of the British Arachnological Society 7: 269-272.

Caporiacco L. di. 1940. Aracnidi raccolti nella regione dei Laghi Etiopici della Fossa Galla. Atti della Reale Accademia d'Italia, Memorie della Classe di Scienze Fisiche, Matematiche e Naturali 11: 767872.

Dippenaar-Schoeman A.S. \& Jocqué R. 1997. African Spiders: An Identification Manual. Plant Protection Research Institute Handbook 9. Agricultural Research Council, Pretoria.

El-Hennawy H.K. 2011. Notes on spiders of Africa - II (Madagascar, Seychelles, Aldabra, Comoro Is., Réunion, Mauritius, and Rodriguez). Serket 12: 91-112.

Kronestedt T. 1987. On some African and Oriental wolf spiders (Araneae: Lycosidae): redescription of Pardosa oncka Lawrence from Africa, with notes on its generic position. Journal of Natural History 21: 967-976. http://dx.doi.org/10.1080/00222938700770581

Kronestedt T. 1993. Species of Wadicosa (Araneae: Lycosidae): revised generic allocation of Lycosa quadrifer Gravely from Sri Lanka and India. Journal of Natural History 27: 313-321. http://dx.doi. org/10.1080/00222939300770161

Kronestedt T. \& Zyuzin A.A. 2009. Fixation of Lycosa fidelis O. Pickard-Cambridge, 1872 as the type species for the genus Wadicosa Zyuzin, 1985 (Araneae: Lycosidae), with a redescription of the species. Contributions to Natural History 12: 813-828. 
Oyediran I.O., Traore A.K.A. \& Heinrichs E.A. 2000. Ground-dwelling arthropods in upland and hydromorphic rice in Côte d'Ivoire. Insect Science and Its Application 20: 81-90. http://dx.doi. org/10.1017/S1742758400018713

Roewer C.F. 1959. Araneae Lycosaeformia II (Lycosidae). Exploration du Parc National de l'Upemba, Mission G.F. de Witte 55: 1-518.

Saaristo M.I. 2010. Araneae. In: Gerlach J. \& Marusik Y. (eds) Arachnida and Myriapoda of the Seychelles Islands: 8-306. Siri Scientific Press, Manchester.

Siyam M., Dunlop J.A. \& El-Hennawy H.K. 2015. New spider records from the Republic of Sudan. Arachnology 16: 264-272. http://dx.doi.org/10.13156/arac.2015.16.7.264

Uhl G., Nessler S.H. \& Schneider J.M. 2010. Securing paternity in spiders? A review on occurrence and effects of mating plugs and male genital mutilation. Genetica 138: 75-104. http://dx.doi.org/10.1007/ $\underline{\text { s10709-009-9388-5 }}$

World Spider Catalog. 2015. World Spider Catalog. Natural History Museum Bern. Available from http://wsc.nmbe.ch, Ver. 16 [accessed on 15 Apr. 2015]

Wunderlich J. 1987. Die Spinnen der Kanarischen Inseln und Madeiras: Adaptive Radiation, Biogeographie, Revisionen und Neubeschreibungen. Triops Verlag, Langen.

Yan Y.C. \& Yan H.M. 2007. Phylogenetic relationships of Wadicosa in Chinese wolf spiders (Lycosidae, Wadicosinae). Acta Zootaxonomica Sinica 32: 996-999 [in Chinese, with English summary].

Yin C.M., Peng X.J. \& Zhang Y.J. 1997. One new species of the genus Wadicosa (Araneae, Lycosidae) from China. Acta Arachnologica Sinica 6: 99-101.

Zehethofer K. 1998. Zum Vorkommen einer Wadicosa-Art in Sabah, Nord-Borneo (Araneae: Lycosidae). Berichte des Naturwissenschaftlich-Medizinischen Vereins in Innsbruck 85: 161-165.

Zyuzin A.A. 1985. Generic and subfamilial criteria in the systematics of the spider family Lycosidae (Aranei), with the description of a new genus and two new subfamilies. Trudy Zoologicheskogo Instituta, Leningrad 139: 40-51 [in Russian, with English summary].

Manuscript received: 24 April 2015

Manuscript accepted: 9 June 2015

Published on: 10 August 2015

Topic editor: Rudy Jocqué

Desk editor: Danny Eibye-Jacobsen

Printed versions of all papers are also deposited in the libraries of the institutes that are members of the EJT consortium: Muséum National d'Histoire Naturelle, Paris, France; Botanic Garden Meise, Belgium; Royal Museum for Central Africa, Tervuren, Belgium; Natural History Museum, London, United Kingdom; Royal Belgian Institute of Natural Sciences, Brussels, Belgium; Natural History Museum of Denmark, Copenhagen, Denmark. 